\title{
Tecnura
}

\section{Geo-inspired model: Agents vectors naturals inspired by the environmental management (AVNG) of water tributaries}

\author{
Modelo geo-inspirado: Agentes vectores naturales inspirados \\ en la gestión ambiental (AVNG) de los afluentes hídricos
}

\begin{abstract}
Edwin Eduardo Millán Rojas', José Nelson Pérez Castillo², Fredy Antonio Verástegui González³
\end{abstract}
Fecha de recepción: 11 de enero de 2017

Fecha de aceptación: 10 de agosto de 2017

Cómo citar: Millán Rojas, Edwin Eduardo, José Nelson Pérez Castillo, y Fredy Antonio Verástegui González (2017). Geo-inspired model: Agents vectors naturals inspired by the environmental management (AVNG) of water tributaries. Tecnura, 21(54), 68-78. https://doi.org/10.14483/22487638.12958

\section{Abstract}

Context: Management to care for the environment and the Earth (geo) can be source of inspiration for developing models that allow addressing complexity issues; the objective of this research was to develop an additional aspect of the inspired models. The geoinspired model has two features, the first covering aspects related to environmental management and the behavior of natural resources, and the second has a component of spatial location associated with existing objects on the Earth's surface.

Method: The approach developed in the research is descriptive and its main objective is the representation or characterization of a case study within a particular context.

Results: The result was the design of a model to emulate the natural behavior of the water tributaries of the Amazon foothills, in order to extend the application of the inspired models and allow the use of elements such as geo-referencing and environmental management. The proposed geoinspired model is called "natural vectors agents inspired in environmental management".
Conclusions: The agents vectors naturals inspired by the environmental are polyform elements that can assume the behavior of environmental entities, which makes it possible to achieve progress in other fields of environmental management (use of soil, climate, flora, fauna), and link environmental issues with the structure of the proposed model.

Keywords: Environment, georeferencing, flood, bioinspired model environmental problem.

\section{Resumen:}

Contexto: La gestión para cuidar el medio ambiente y la Tierra (geo) puede ser una fuente de inspiración para desarrollar modelos que permitan abordar problemas de complejidad; el objetivo de esta investigación fue desarrollar un aspecto adicional de los modelos inspirados. El modelo geoinspirado tiene dos características, la primera cubre aspectos relacionados con la gestión ambiental y el comportamiento de los recursos naturales, y la segunda tiene un componente de ubicación espacial asociado con objetos existentes en la superficie de la Tierra.

1 Systems engineer, specialist in Software Engineering, magister of Science in Information and Communication, doctor in Engineering. University of Amazonia. Florencia, Colombia. Email: e.millan@udla.edu.co

2 Systems engineer, specialist in Geographic Information Systems, magister of Teleinformática, doctor in Computer. District University Francisco José de Caldas. Bogotá, Colombia. Email: jnperezc@correo.udistrital.edu.co

3 Systems engineer, systems Audit Specialist, magister of Science in Information and Communication. University of Amazonia. Florencia, Colombia. Email: f.verastegui@udla.edu.co 
Método: El enfoque desarrollado en la investigación es descriptivo y su principal objetivo es la representación o caracterización de un estudio de caso dentro de un contexto particular.

Resultados: El resultado fue el diseño de un modelo para emular el comportamiento natural de los afluentes del agua de las estribaciones del Amazonas, con el fin de ampliar la aplicación de los modelos inspirados y permitir el uso de elementos como la georreferenciación y la gestión ambiental. El modelo de geoinspiración propuesto se denomina "agentes de vectores naturales inspirados en la gestión ambiental".
Conclusiones: Los agentes vectores naturales geoisnpirados son elementos poliformados que pueden asumir el comportamiento de las entidades ambientales, lo que permite avanzar en otros campos de gestión ambiental (uso del suelo, clima, flora, fauna) y vincular las cuestiones ambientales con la estructura del proyecto modelo.

Palabras clave: Medio ambiente, georreferenciación, inundación, modelo bioinspirado, problema ambiental.

\section{INTRODUCTION}

In the following work will be unveiled natural delivery agents (AVNG) environmental management-inspired water tributaries in order to expand the fields and functionality of a Bio-inspired model (Cruz, N. A. G., \& Maldonado, C. E., 2011). The research implements general objective development of the model for natural delivery agents' environmental management-inspired (AVNG) water tributaries of the Colombian Amazon Piedmont. One of the factors to consider is the natural resources that each day require greater capacity to support the solution of environmental problems, is this field where the environmental management contributes to finding solutions in different environments, the flora, fauna, water resources, land use, and climate change, among others. These solutions are at the heart of advancements to improve the environment and therefore the quality of life of the people. Different elements have been developed from the field of computer science for environmental information management support (Wang, X., \& Sun, Z., 2013), (Sanders, B. F. (2007), (Zeng, R. 2012), (Agenda Ambiental Andina 2012-2016). The need to tune the advanced developments of the computer with the environmental management to help achieve its purpose is the source of research developed at present. Some of these advanced developments are models bioinspired which have allowed tackle computationally complex problems and give a solution from biology (Yang, X. S., Cui, Z., Xiao, R., Gandomi, A. H., \& Karamanoglu, M. (Eds.), 2013) y (Fathi, A., \& Mozaffari, A., 2014). The proposed geoinspired model sets the behavior on the environmental management (control) and manages to consolidate geo-referenced information. The AVNG are the representation of environmental entities. This first phase of research seeks to arrive at an approximation of environmental management with a case study: the flood that affects the area of the Amazon Piedmont in the Department of Caquetá. This phenomenon caused by water tributaries each year leave disasters in this part of the Colombian territory (Guhl Nannetti, E. 2012). There are tools from computer science contributing to the main sources of environmental risk management exercise conducted in china that show a set of modules made in ArcGis Engine, .NET and Oracle, a management module of basic environmental information, module reports source of business risk and source of risks audit and management module, full of the aforementioned work detail can be found in Ma, S., Zhang, S., Chen, y., \& Zheng, H., 2013. This clearly shows the integration of information with environmental management systems. Other examples related to the management of environmental management in the water sources, the 
use of the soil, flora and fauna can be found in the following works Heuberger, p. S. C. 1995, Larssen, T., Hogasen, T., \& Cosby, B. J. 2007.

\section{METHODOLOGY}

The methodological approach is theoretical, structured, and systemic; the main methodological strategy is based on making a constant reformulation of the theoretical, methodological aspects and guidelines of validity. This perspective leads to the use of various quantitative and qualitative techniques since, as Lorenzo Blanco recognizes it, between two perspectives there is complementarity and unnecessary (Alvira Martín, F., 1993).

The purpose of this methodology (figure 1) is to provide a tool for the integration of managed environmental and computer bioinspired informatiom from the case study: the phenomenon of flooding caused by the water resources of the Colombian Amazon Piedmont (Florencia, Caqueta).

\section{Methodological development}

\section{Description of the environmental entity}

This phase of the methodology is a study of the environmental phenomenon that is intended to address. It is initially a description of the problem related environmental entity, and it contextualizes and delimits in order to proceed to the next stage.

Environmental entity: Creek, their behavior will be a source of inspiration to consider variables to emulate the object of study.

Hydrographic basin: "It is the space that collects the water of pluvial precipitation, radiant and energy, according to the physiographic, geological, and soil

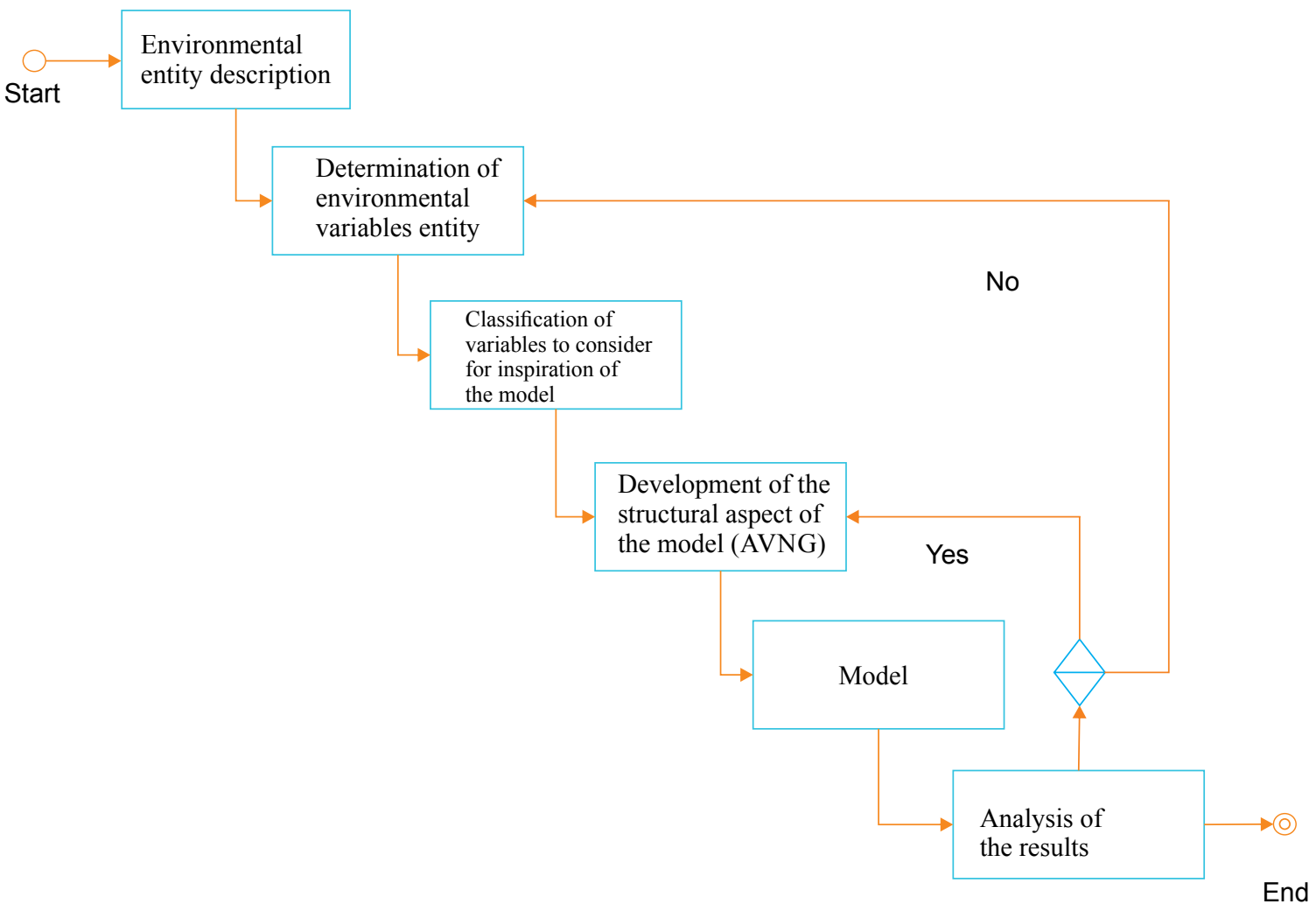

Figure 1. Methodology proposal

Source: own work. 
ecological characteristics. It stores, distributes, and transforms water and energy in the most complex and varied natural resources, which are those that determine the degree of development of the basin until reaching its peak, where it reaches its greatest energy accumulation, and finally are at the service of human society, for its rational use (Creek)" taken from (Caldas, D. Gloria Umaña Gloria Padilla, 2010)".

According to (Chorley, Schumm \& David, 1984), the regime of the River as the form that takes the channel of a stream is determined by the slope, flow and sediment load conditions: three independent variables associated with the dynamics of the fluvial of alluvial rivers.

\section{Determination of the variables of the entity and the environmental problem}

Precipitation: The significant variables associated with precipitation are: (1) current, (2) duration, (3) depth, (4) frequency, (5) temporal distribution, (6) spatial distribution, and (7) area correction (Looper \& Vieux, 2012).

Average precipitation: The determination of the average volume of water charging a basin is the estimated potential of values collected over a time interval. The values are calculated from data collected at stations located in the area of the basin. Once the data is processed, the value of the average of the measurements obtained is calculated (Pizarro \& Ramírez,2003). In all cases, the average rainfall is calculated, so three methods are commonly used: average arithmetic, Thiessen polygons, and Isohietas, a description of these methods can be found at (López Bermúdez, 1972).

Hydrological abstractions: Hydrological abstractions are physical processes that Act to reduce the total precipitation effective precipitation (Stehli,Weber \& Jorquera,2012). The variables to consider are the following: (1) interception, (2) infiltration, (3) storage of surface, (4) evaporation and evapotranspiration (5) (Stehli, et al, 2012).

Draining: In the field of models two types of runoff can be recognized: (1) water in the basin and (2) water in the stream channel. "Basin runoff has three-dimensional features, but eventually this type of runoff is concentrated at the exit of the basin. After leaving the basin runoff enters the canal network where it becomes a flow of channel. Unlike the basin runoff, the marked longitudinal orientation of the flow of the stream channel usually justifies assumed one-dimensional" taken from (Guía del trabajo practico $N^{\circ} 2,2014$ ).

Area and perimeter of the basin: The area of the basin is important because it is the basis to calculate items related to the slope, runoff and other factors that affect the flow of the environmental entity (Stehli, et al 2012).

Average slope of the watershed: The average slope is the sum of the values of partial slopes calculated along the main path of the environmental authority; an important element in the effect of the water falling to the surface, by the speed that acquires and erosion that produces (Martínez-Martínez \& Campos-Aranda, 2010).

The slope of the main channel of the watershed: "The slope of a stretch of river is considered as the gap between the ends of the section, divided by the horizontal length of the said section" Reprinted from Precipitación observada en la Estación.

Cauda: "Refers primarily to the hydraulic volume of runoff from a catchment in the main river of the same. Usually measured in $\mathrm{m}^{3} / \mathrm{sec}$ which generates an annual value measured in $\mathrm{m}^{3}$ or in million cubic metres (cubic hectometres: a million cubic metres is equivalent to one million $\left.\mathrm{m}^{3}\right)^{\prime \prime}$, Reprinted from Ávila Díaz, Carvajal Escobar\& Gutiérrez Serna (2014).

\section{Classification of variables to consider for the inspiration of Model}

The classification of the variables to take into account in this first approach is influenced by the environmental problem to be treated. As stated in the first part of the article, heavy rains in the amazonic Foothill cause the floods. The above are classified by the following variables: (1) flow rate, (2) medium slope of the basin, (3) surface and the perimeter of the basin, (4) average rainfall. 
Flow is the source of the energy to be able to transport water through the channel of the water effluent, the value of the slope is crucial to increase or decrease the speed of the water during the flood. Surface and the perimeter of the basin determines the area that helps collect water to the main channel and the average rainfall is the external variable chosen for this study as responsible for the occurrence of the problem of flooding.

\section{Development of the structural aspect of the model (AVNG)}

The structuring of the model were grouped variables identified previously in three groups: the first natural function, which makes the object of study continuously and is not significantly influenced by the environment, this function is defined as the natural behavior of the environmental entity. The second is the environmental management function, which is defined by the intervention of man and looking for generating a control over the natural function, which is affected by the third function, the latter is what defines the sudden or continuous change on the entity and is generated directly by one or more of the variables affecting the normal performance of the natural function. Then proceed to group variables and define functions:

Natural function: To calculate the flow equation (1) runway section is divided into subsections and half the distance (semi-distance) adds to the adjacent vertical, you can calculate the flow rate (Castro, Barbosa \& Ortiz, 2015).

$$
\sum_{i=0}^{n} Q_{i}=\sum_{i=0}^{n} V_{i} h_{i}\left(\frac{b_{i-1}}{2}+\frac{b_{i+1}}{2}\right)
$$

Where: $i=$ sections defined in the riverbed, $Q=$ value of the flow in a section $i, V=$ velocity of the flow in the section $i, h=$ height of the section $i$, and $b=$ section half taken to divide the sections

The variable to be considered in the natural feature is the speed of the runway equation (2) is obtained from take as valid expression of Chézy see Badano, Sabarots Gerbec, \& Menéndez, (2011).

$$
V_{i}=C_{i} \sqrt{R h_{i}} S_{i}
$$

$V i=$ speed flow of water in the section $i$ considered average, $\mathrm{Ci}=$ Chezy coefficient in the section $i$ considered, $R h i=$ hydraulic RADIUS in the section $i$ considered, $S_{i}=$ average gradient in the considered section $i, K=$ constant, and $T=$ total time of water flow along the runway.

There is also a variable that influences the natural function see equation (3) constantly in this study is the solar radiation that can contribute to evapotranspiration in the gorge, this variable is taken at random.

$$
\sum_{i=0}^{n} Q_{i}=\sum_{i=0}^{n}\left(V_{i} h_{i}\left(\frac{b_{i-1}}{2}+\frac{b_{i+1}}{2}\right)\right)+v a_{i}
$$

va $=$ Random variable.

Function problem: For practical purposes this agent function is defined as a flood or high increase of the runway, the function problem is equal to the natural function over the influence of the environment (precipitation) variable see equation (4); This variable influences directly on the value of the flow rate.

$$
\sum_{i=0}^{n} Q_{i}=\sum_{i=0}^{n}\left[\left(V_{i} h_{i}\left(\frac{b_{i-1}}{2}+\frac{b_{i+1}}{2}\right)\right)+v a_{i}\right] P m
$$

$\mathrm{Pm}=\mathrm{It}$ is the value of the precipitation average that falls on all sections of the tributary.

Environmental management function: The function of environmental management is to control the natural function when it is influenced by the environment variable and implements the function problem. The function seeks to have degrees of tolerance between the natural function and the function problem in order to issue an alert when it is above the limits.

Function of the environment: For the present study, the function of environment is defined as function or variable precipitation, average precipitation specific environment (see equation 5), which is the resulting value of sampling stations for monitoring the surface of the basin. The method of the Thiessen polygons is used to calculate the rainfall 
(Pizarro, r. et al 2003) in which it is necessary to the location of each station inside or on the periphery of the basin to proceed with the application.

$$
\bar{P}=\sum_{i=1}^{n}\left(P_{i} \cdot \frac{A_{i}}{A}\right)
$$

Where $\bar{P}=$ rainfall over the basin, $P_{i}=$ precipitation observed at the station $i, A i=$ area of the polygon to the station $i, A=$ total area of the basin and $n=$ number of pluviometric stations or gauging with influence in the basin.

\section{RESULTS}

\section{Geoinspired Model}

\section{Support elements to the model proposed}

The geoinspired model requires elements of support (figure 2) for the purpose of performing a deployment in a controlled environment to validate the results:

Category: Environmental management for this study has been divided into four main categories:
Hydrography, use of soil, climate, flora and fauna. Category 1 will be addressed initially. Hydrography caused by water tributaries flood related.

Problem: It is defined as the autonomous natural phenomenon that occurs when you modify the natural function of the geographical entity, through human intervention or natural causes. The flood is an environmental problem generated by the location of urban settlements close to the tributaries of water. It is also caused by deforestation and the pollution of the tributaries. In the Amazonian Piedmont, in the municipality of Florence the Perdiz Creek, which flows through the capital of the Department of Caquetá, each year causes this phenomenon causing material losses and human lives according to Cortés, (2004), entity responsible for monitoring this phenomenon.

Classifier of entities: It is the module responsible for defining the behavior of the phenomenon and the variables involved in the problem, and characterizes the studied entity.

Proposed model natural vectors agents geoinspired: The AVNG may represent the environmental

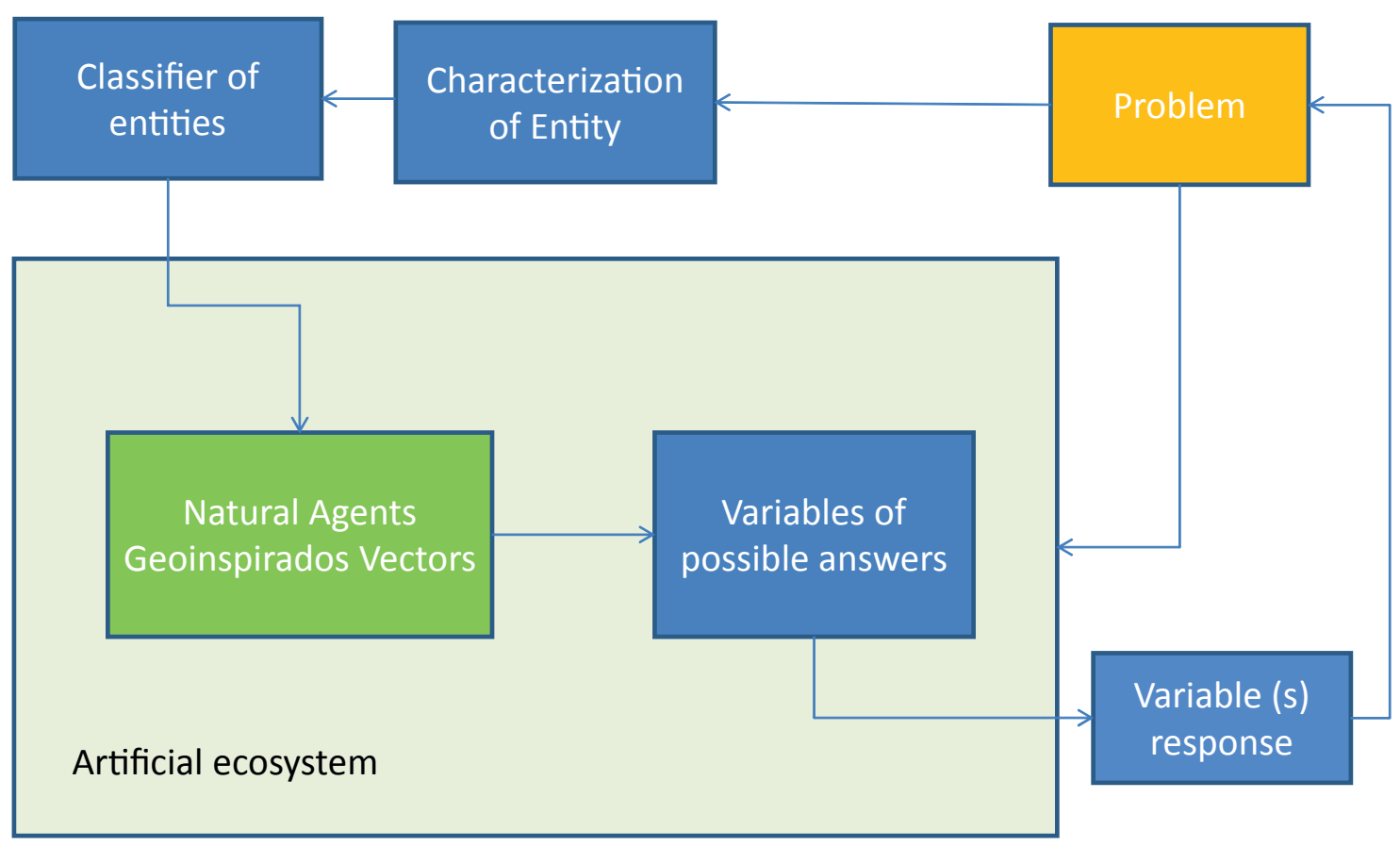

Figure 2. Elements of support to the proposed model

Source: own work. 
entity in an artificial context, where its functions are defined to find possible answers to the problem.

Artificial ecosystem: It is a simulated environment where the agents interact to find a solution to the problem.

Variables of possible answers.: It is the set of variables that can deliver the AVNG once running on the artificial ecosystem.

Response variable: It is or they are significant variables that come close to solving the problem or give an alert when the problem occurs.

\section{Elements of the natural vector agent model geoinspired (AVNG)}

The following are elements that make up the AVNG: Natural agent function, function problem, memory, function environmental management (Control), geographical feature, function or variable from the environment and random variable, see figure 3 . Key elements were inspired by elements related to the environmental entity, and were described in the development of the methodology in the phase of the preparation of the aspect structural of the model (AVNG).

Natural function of agent: It identifies the geographic entity that was inspired by the flow of the case study.

Function problem: It is the function that determines the behavior of the environmental entity; it is influenced by the variable or the function of the environment and causes the problem. For the purposes of the present study, ths was inspired by the flood.

Memory: Variable necessary to keep the information generated by each agent; it can be used as variable input or output of the functions of the agent.

Environmental management function (Control): It is inspired by the need to control the problem, which is caused by the execution of the function problem influenced by environment and own random variable

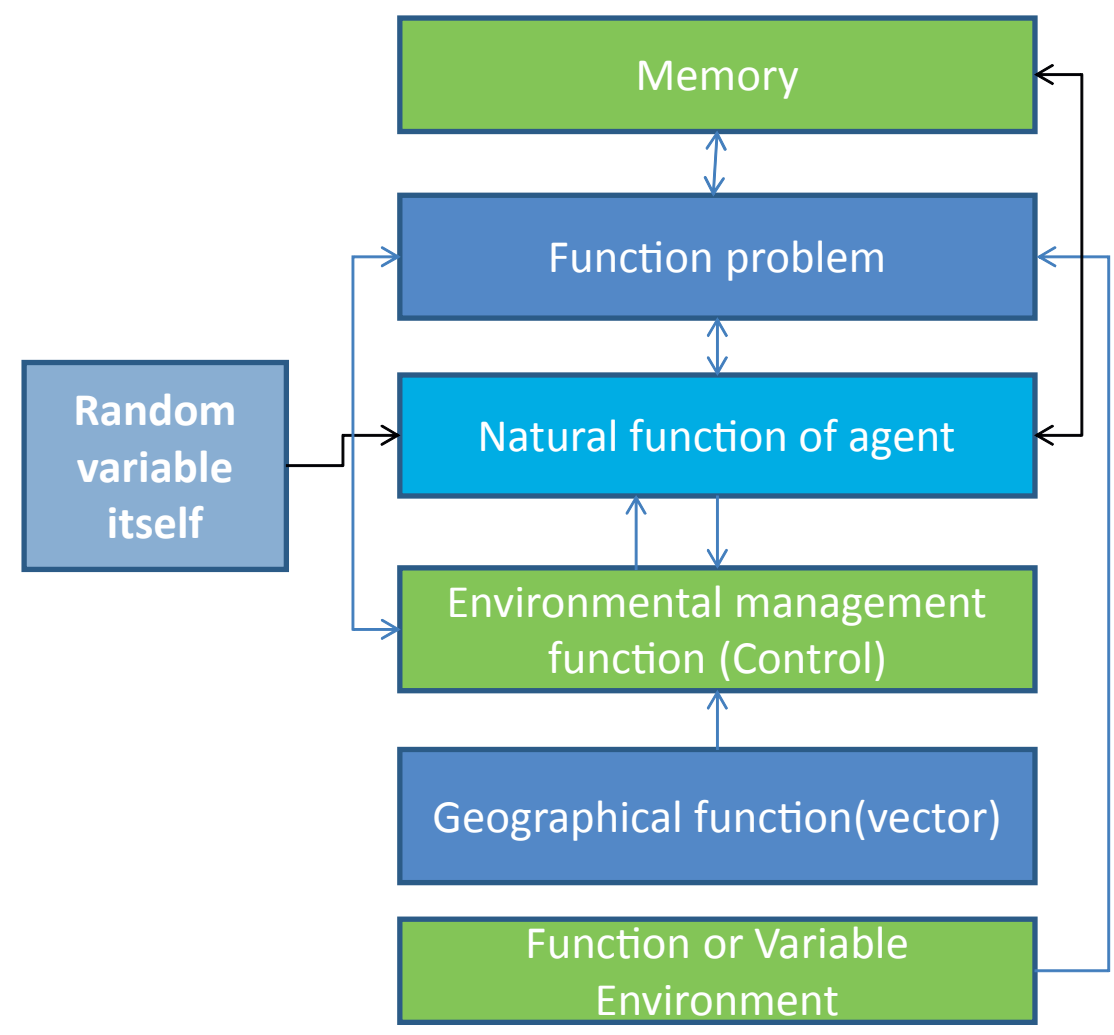

Figure 3. Structure of the vector agent natural geoinspired (AVNG)

Source: own work. 
Geographical function (vector): It allows vector agent and locate it geographically consists of flat or geographical coordinates.

Function or Variable Environment: This function directly affects the behavior of the agent and is inspired by rainfall.

Random variable itself: In the environmental context all the geographic entities possess random behavior that defines certain patterns, this variable was inspired by those behaviors.

\section{Analysis of the results}

The proposed model can be implemented using the representation of an environmental entity in parts (see figure 4), or representing the entity through an AVNG (figure 5). The AVNG can be deployed in future research in other categories of environmental management.

\section{Artificial ecosystem}

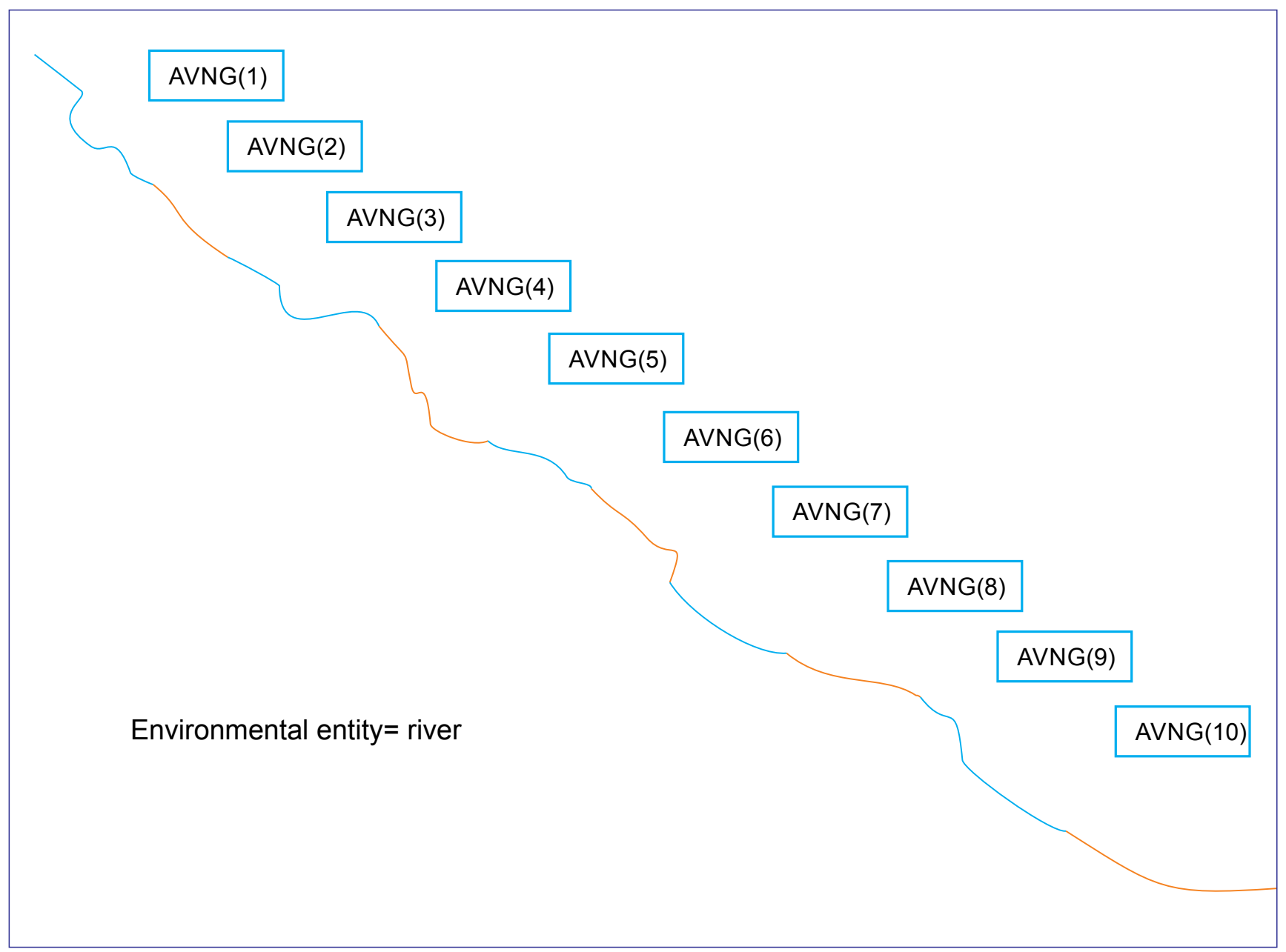

Figure 4. Representation of the environmental entity by Parties (10 Agents)

Source: own work. 


\section{Artificial ecosystem}

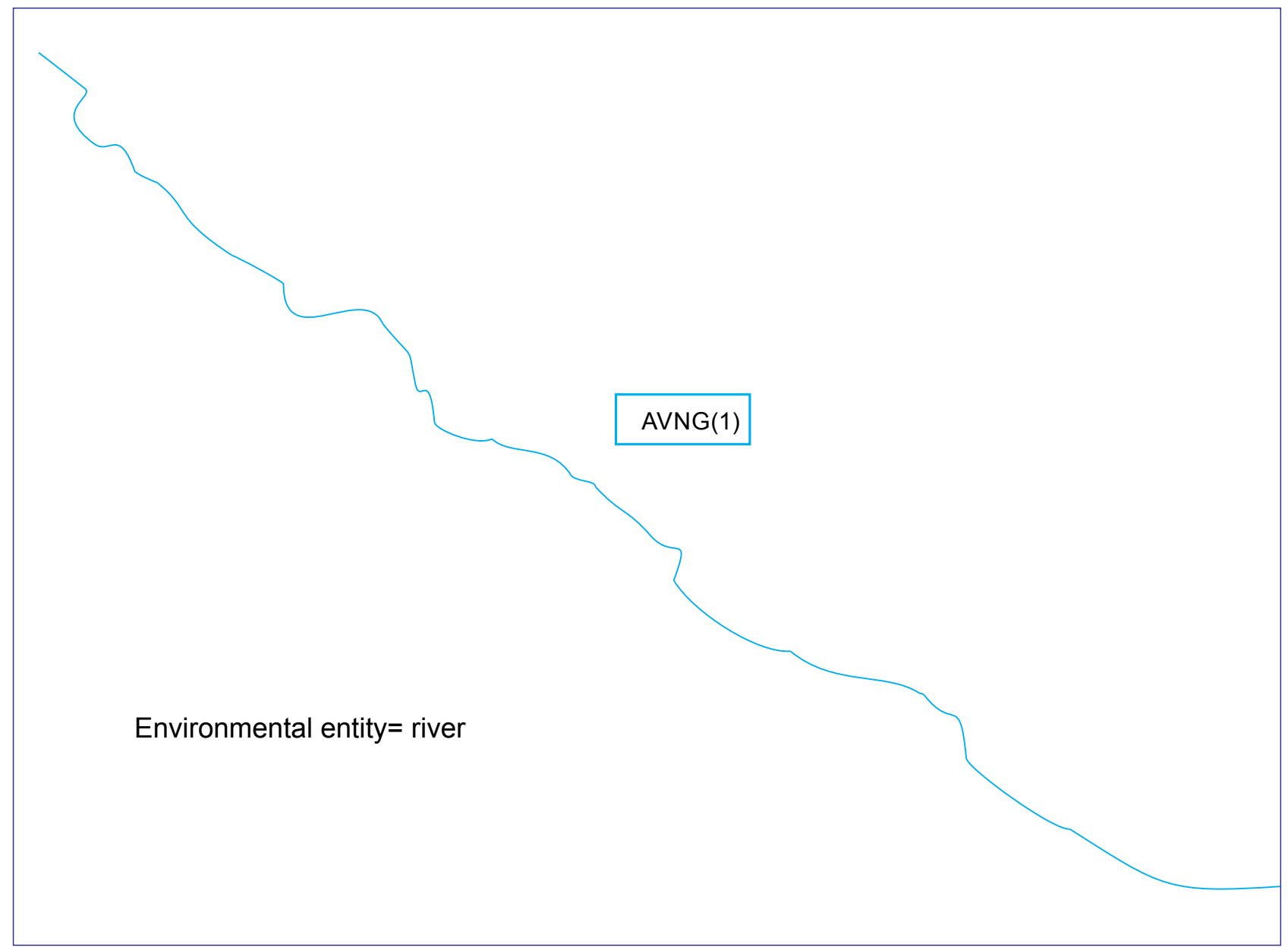

Figure 5. Representation of the environmental authority (1Agent)

Source: own work.

The model represents an approximation of the geographical entity and the problem being addressed however can demonstrate that it is necessary to investigate the variables of any phenomenon in order to approach to the solution of the problem to be treated.

Differential aspects with the model bioinspired AVNG model is polyform, can take the form of any environmental entity, and is not restricted to a single behavior. The geographical feature that permits to determine the location of the agent used two additional functions, but this feature also restricts the agent in a particular context. The second function is to control, which allows the auto regulation of the agent with its surroundings, and at the same time provides information for the response variables.

\section{CONCLUSIONS}

The model of delivery agents geoinspired can be used to represent environmental water bodies such as rivers, creeks and tributaries. 
The model determines the behavior of environmental organizations in the category of hydrography in environmental management.

The development of the model geoinspired was achieved from an environmental entity, which inspired a new model agent with vector characteristics and related environmental management (control).

AVNG model contributes to the symbolic representation of the environmental elements.

An environmental entity can be represented as a whole or as a set of elements that have the same characteristics of the environmental organization.

The proposed model generates response variables to the environmental problem from integration of agents.

\section{FINANCING}

The development of this research is highlighted in the framework of the Doctoral training at the Universidad Distrital Francisco José de Caldas, funded by the University of the Amazonia as part of doctorate-level teacher training policy.

\section{REFERENCES}

Agenda Ambiental Andina (2012-2016). It guides the actions of a subregional character of Bolivia, Colombia, Ecuador and Peru in biodiversity, climate change and water resources.

Alvira Martín, F. (1983). Qualitative-quantitative methodology sociological perspectives perspectives. Revista Española de Investigaciones sociológicas, 22, 53-76.

Ávila Díaz, Á. J., Carvajal Escobar, Y., \& Gutiérrez Serna, S. E. (2014). Análisis de la influencia de El Niño y La Niña en la oferta hídrica mensual de la cuenca del río Cali. Tecnura, 18(41), 120-133. https://doi.org/10.14483/ udistrital.jour.tecnura.2014.3.a09

Badano, N. D., Sabarots Gerbec, M., Re, M., \& Menéndez, A. N. (2011). Desarrollo y aplicación de un modelo acoplado hidrodinámico-sedimentológico basado en OpenFOAM. In XIX Congreso sobre Métodos Numéricos y sus Aplicaciones, ENIEF.

Butler, D. R. (1986). Geomorphology, Richard J. Chorley, Stanley A. Schumm, and David E. Sugden, 1984, Metheun \& Co.

Caldas, D. Gloria Umaña \& Gloria Padilla (145, 2010). Un proyecto de educación ambiental con los docentes del municipio de caldas (Boyacá). Revista de la Facultad de Artes Y Humanidades.14.

Castro, G. E. A., Barbosa, T. E. G., \& Ortiz, E. A. S. (2015). Comportamiento de las ecuaciones de Saint-Venant en 1D y aproximaciones para diferentes condiciones en régimen permanente y variable. Tecnura, 19(45), 75. https://doi.org/10.14483/udistrital.jour. tecnura.2015.3.a06

Cortés, N. G. H. (2004). Geomorfología e hidrología, combinación estratégica para el estudio de las inundaciones en Florencia (Caquetá). Cuadernos de geografía, (13), 81.

Chorley, R. J., Schumm, S. A., \& David, E. (1984). Geomorphology. New York: Methuen.

Cruz, N. A. G., \& Maldonado, C. E. (2011). Bioinspired systems: A theoretical framework for complex systems engineering. Bogotá: Editorial Universidad del Rosario.

Fathi, A., \& Mozaffari, A. (2014). Modeling a shape memory alloy actuator using an evolvable recursive black-box and hybrid heuristic algorithms inspired based on the annual migration of salmons in nature. Applied Soft Computing, 14, 229-251. https://doi. org/10.1016/j.asoc.2013.03.019

Guhl Nannetti, E. (2012). De la vorágine a la tierra de promisión: Notas sobre visiones, valoración y contexto internacional de la Amazonia. Revista de la integración, 9.

Larssen, T., Høgåsen, T., \& Cosby, B. J. (2007). Impact of time series data on calibration and prediction uncertainty for a deterministic hydrogeochemical model. Ecological 
Modelling, 207(1), 22-33. https://doi. org/10.1016/j.ecolmodel.2007.03.016

López Bermúdez, F. (1972). The water in the basin of the Segura. Papers of geography, 4.

Looper, J. P., \& Vieux, B. E. (2012). An assessment of distributed flash flood forecasting accuracy using radar and rain gauge input for a physics-based distributed hydrologic model. Journal of Hydrology, 412, 114-132. https:// doi.org/10.1016/j.jhydrol.2011.05.046

Ma, S., Zhang, S., Chen, Y., \& Zheng, H. (2013). Design and realization of a major environmental risk source management system. Procedia Environmental Sciences, 18, 372-376. https:// doi.org/10.1016/j.proenv.2013.04.049

Martínez-Martínez, S. I., \& Campos-Aranda, D. F. (2010). Algorithms for estimating physical characteristics in rural watersheds and its application in the calibration of the rational method in hydrological region no. 12 partial (Santiago River). Agrociencia, 44(4), 393-408.

Pizarro, R., \& Ramírez, C. (2003). Comparative analysis of five methods for the estimation of annual areal rainfall in extreme periods. Bosque (Valdivia), 24(3), 31-38.

Guía del trabajo practico № 2. (2014). Retrieved on August 27, 2014, from http://ing.unne.edu. ar/pub/hidrologia/hidro-tp2.pdf.
Sanders, B. F. (2007). Evaluation of on-line DEMs for flood inundation modeling. Advances in Water Resources, 30(8), 1831-1843. https:// doi.org/10.1016/j.advwatres.2007.02.005

Stehli P.T., Weber J.F., Jorquera E. (2012). Implementación de un modelo hidrológico espacialmente distribuido de simulación de eventos. Paper presented at the Primer Encuentro de investigadores en formación en Recursos Hídricos. Ezeiza, Bs. AsUmaña, G. \& Padilla, G. A project of environmental education with teachers in the municipality of Caldas. Revista Folios, 14.

Wang, X., \& Sun, Z. (2013). The Design of Water Resources and Hydropower Cloud GIS Platform Based on Big Data. In F. Bian,Y. Xie, X. Cui, Y. Zeng (Eds.), Geo-Informatics in Resource Management and Sustainable Ecosystem (pp. 313-322). Berlin: Springer. https:// doi.org/10.1007/978-3-642-41908-9_32

Yang, X. S., Cui, Z., Xiao, R., Gandomi, A. H., \& Karamanoglu, M. (Eds.). (2013). Swarm intelligence and bio-inspired computation: Theory and applications. London: Elsevier. https://doi.org/10.1016/ B978-0-12-405163-8.00001-6

Zeng, R. (2012). Infrastructure planning for drought mitigation under climate change (Master thesis), University of Illinois at Urbana-Champaign, Illinois. 